\title{
Research on the Public Communication Platform Construction for College Students' Innovation and Entrepreneurship Education
}

\author{
Li Qing \\ College of Business Administration, Ningbo Dahongying University, Ningbo, Zhejiang, China \\ zhaojy80@163.com
}

Keywords: Public Communication Platform, Construction, College Students' Innovation, Entrepreneurship Education

\begin{abstract}
Under the new economic normal, university students find it hard to get employed. Entrepreneurship education has become an important mission entrusted by the times to higher education. This paper conducts an empirical research on the impact of current entrepreneurship education on college students' willingness to start their own business. It finds that entrepreneurial curriculums, entrepreneurship talks, entrepreneurial competitions, entrepreneurial practices and entrepreneurship exchange platforms have a significant impact on the entrepreneurial intentions of college students, and are positively affected. It further explores the new path from campus culture construction, perfect communication platform, reform and innovation teaching, sets up practice base, financing guarantee and key teacher training, promoting the development of entrepreneurship education.
\end{abstract}

\section{Introduction}

In May 2014, Xi Jinping first mentioned the term "new normal" in his visit to Henan. "New" is different from the old, different past. "Normal" means relatively stable. This means that the emergence of new characteristics of China's economic development is also a trend of irreversible development. That is, our economy has shifted from high-speed growth to medium-high-speed growth, the economic structure has been optimized and upgraded, from element-driven and investment-driven to Innovative drive.

Under the new normal economic development, the slowing down of economic growth has reduced the demand for labor in the market, and the employment pressure of graduating graduates has been raised again due to the expansion of universities. At the same time, the slowdown in economic growth has highlighted the long-standing structural contradictions in employment which directly indicate the emergence of mismatches in the quality of human resources and the employment needs of the market. Dual pressures lead to structural unemployment now exists in large numbers, the problem of employment of college students continue to ferment.

\section{The Necessity for Entrepreneurship Education}

Many college entrepreneurship education courses lack of continuity, normative and systematic, there is no professional textbooks, there is no perfect education system, there is no systematic norms teaching mode, the form is greater than the content, resulting in students boredom entrepreneurship, lack of interest. Many colleges and universities spend huge sums of money inviting business elites to teach entrepreneurship skills and hold entrepreneurial competitions, but such entrepreneurship education lacks a sound system and rich curriculum configuration with little success.

Teachers are the leading teaching, high-quality entrepreneurship education faculty is to carry out entrepreneurship education, the premise and guarantee. However, at present, colleges and universities have many problems in the construction of entrepreneurial faculty. Many teachers simply give lectures to students' immediately after training or without training. They tend to teach 
theories that tend to be simple, lack the necessary entrepreneurial practices and are lacking System, mature teaching methods. Entrepreneurship education cannot be confined to the classroom theory of theoretical study, but also to strengthen the accumulation of practical experience.

Entrepreneurship education in colleges and universities is aimed only at undergraduate students, and terminates at university, lack of long-term entrepreneurship education and training platform, cannot be given to graduate after the help of ethnic college students. In fact, many college students start their own business after graduation. They encounter various difficulties and obstacles in starting a business. However, it is inevitable that entrepreneurship education and guidance must not be fewer. However, it is hard to get guidance from colleges and universities and lack a long-term platform for entrepreneurship education and training. As a qualified builder and a reliable successor to colleges and universities carrying socialism with Chinese characteristics, the university actively performs its duties and responds to the strategy put forward by the 17th National Congress of the Communist Party of China to expand employment and promotes the policy guideline of starting a business by starting a career. In career planning courses initiate entrepreneurship education system. The validity of this policy has also been confirmed by empirical studies conducted by some scholars. Entrepreneurship can indeed promote employment. The effect of employment on different stages of entrepreneurship is different. For every $1 \%$ increase in starting a business, the employment will increase by $0.11-0.22 \%$. In the context of the new economy, entrepreneurial education will undoubtedly become an important mission given to higher education by the times.

First, entrepreneurial education becomes an important way to solve the difficult employment of college graduates. Second, entrepreneurial education can promote self-development and enhance one's own value. Third, entrepreneurial education provides intellectual support for creating an innovative nation. Less willingness to start a business for college students has not significantly affected.

\section{Innovation and Entrepreneurship Education Strategy}

\subsection{Enrich Activities, Improve Business Exchange Platform}

Colorful campus cultural activities can guide students to increase their knowledge, training ability, improve their overall quality, lay a good foundation for entrepreneurship. All colleges and universities should launch a variety of activities to participate in a wide range of entrepreneurship competitions, give full play to the campus culture of the second class education function. At the same time, in all types of business activities to professional teachers or entrepreneurs should be set as a mentor, students continue to instill innovative ideas, innovative spirit and entrepreneurial skills, so that students in a relaxed and happy activities to play a pioneering spirit, and practice The operation of timely correction and help. Make full use of new media construction, improve business exchange platform. At present, entrepreneurial associations in colleges and universities have been unable to meet the pursuit of college students. Also need to give full attention to colleges and universities, the use of new media to college students to guide and guide. It is suggested that colleges and universities set up a special team of teachers in charge of online education to give professional guidance to college students while monitoring the new media.

According to the requirement of talent market in the economic market, higher education institutions and enterprises jointly set targets for double-trainee talent cultivation. Enterprises can reflect the knowledge they possess to the personnel training programs according to the position and route of their staff development. The school-enterprise jointly formulates the personnel training programs. As an applied university, we should jointly cultivate innovative talents with enterprises so as to cultivate students to become advanced applied talents with innovative spirit and double ability.

Students as the center, according to CDIO's educational philosophy, closely around the professional quality of professional engineers, professional ability and sense of innovation, close to the needs of the talent market, cultivate the individual development of students through project teaching to promote students' engineering design ability Training, well-designed to capacity-building as the core "project-driven" theory teaching system. In the teaching process, the 
main theory teaching adopts the model of project teaching or the curriculum reform. The content of the lectures is that teachers participate in the project of engaging in post-production training in the enterprise, decompose the project, and at the same time integrate the job tasks of the post into the teamwork, highlighting the job tasks of the job posts.

Use of "project-oriented, task-driven" teaching methods to better develop students 'teamwork, communication and practical ability; the use of self-learning teaching methods to strengthen students' ability to use their knowledge to carry out independent analysis and problem solving. Through the establishment of undergraduate innovation and entrepreneurship training programs, students can choose according to individual hobbies and learning stages of different training programs; by organizing and encouraging students to participate in extra-curricular competitions and practical activities, combined with practical training to continuously improve students' software development capabilities; by participating in schools And provincial and national innovation and entrepreneurship projects of all kinds, the innovative project setup and personnel training programs combine to achieve integration of innovation and entrepreneurship.

\subsection{Innovative Teaching, Set Up Entrepreneurial Practice Base}

In the teaching of entrepreneurship courses, we can not only limit the enlightenment on entrepreneurship, entrepreneurial policies, entrepreneurial factors and other courses, should be added throughout the entrepreneurial a series of courses. Such as the establishment of business management courses, entrepreneurship social knowledge courses, study guidance courses. At the same time, it is suggested that the foundation course for entrepreneurship be set as a compulsory course to supervise teaching quality and popularize entrepreneurship courses in all colleges and universities. Talents finally cultivated by colleges and universities should go to the market and adapt to the market, and the talents trained by entrepreneurship education should create a market. How to combine theoretical knowledge and practice, college entrepreneurship practice base is particularly important. It is to achieve the unity of knowledge and ability, professional skills and entrepreneurial quality of a unified position. In class, we set up design courses such as business planning and design. In class, we actively encourage college students to work part-time and start a business. This will not only provide a safe start-up environment for college students, protect student safety, but also provide additional posts to assist poor students to complete their studies while creating a strong market entrepreneurial atmosphere. Such as the graduation season in June every year, regulate graduates to sell goods at designated locations, college students in the campus to start printing agency.

Construct a perfect entrepreneurship curriculum system. Entrepreneurship courses in colleges and universities is an important part of entrepreneurship education, entrepreneurship education is an important guarantee. In the implementation of entrepreneurship education, colleges and universities should aim at the characteristics, advantages and needs of ethnic minority students to set up a comprehensive and practical course of entrepreneurship education. Of course, we must pay more attention to the implementation of results, can not engage in formalism, blindly implemented. At the same time, we can use a variety of teaching forms to enrich the teaching of entrepreneurship education. For example, we can use flip teaching mode to explore the Internet-based path of entrepreneurship, improve teaching methods and optimize the quality of classroom teaching. On the one hand, we can attract the attention of ethnic college students' force, stimulate students interest in learning, on the other hand to achieve high-quality resource sharing. Entrepreneurship education is a very practical educational discipline, in addition to learning theoretical knowledge, practical experience is essential. Schools can establish a multi-level practice platform to enhance practical training to ensure that the base of adequate quality, multi-dimensional, multi-level innovation and practice platform. For example, the establishment of school practice base, building off-campus practice base, enrich curriculum design practice, enrich the practice of extra-curricular activities, these four aspects are relatively independent and interrelated, showing the practice of multi-dimensional. On the basis of improving the curriculum system for entrepreneurship, colleges and universities can provide entrepreneurs with entrepreneurial practice studios such as 
entrepreneurship studios and hatchery parks, supplemented by entrepreneurial planning competitions, entrepreneurial seminars and entrepreneurship salons to encourage students of ethnic minorities to actively participate in relevant entrepreneurial activities, Stimulate business interest. Finally, it is necessary to improve the incentive mechanism, improve the system of admittance to entrepreneurship among ethnic minority students, expand the coverage of entrepreneurship encouragement fund, and encourage the undergraduates to carry out the innovation and entrepreneurship practice by improving diversified evaluation system.

First of all, schools should improve the awareness and ability of professional teachers in creating students through various ways. They can use the methods of enterprise attachment training and training to help professional teachers improve their ability of practical operation and complete the training of teachers with professional qualifications of "three qualities" Talk about theory, but also can guide the training, but also with enterprises to carry out technical research and development) "double teacher" change, for participating teachers, there should be policy tilt; Second, schools should step up efforts to optimize the structure of teachers, The establishment of a combination of part-time double-hit teachers team, for students to carry out a diversified double education.

\subsection{Guarantee Investment, Strengthen Entrepreneurial Teacher Training}

Entrepreneurship education in the implementation process, whether it is the introduction of teachers, training, social entrepreneurs, entrepreneurs and successful entrepreneurs invited to enter the school, or to help students contact practice internship, campus entrepreneurship practice base to establish and operate, are inseparable from the funding stand by. At this point, colleges and universities should make rational use of funds while absorbing government and social funding support. On the one hand, colleges and universities should set aside a certain amount of funds for entrepreneurial education; on the other hand, they should actively seek the support of social forces to promote successful entrepreneurs, related enterprises and venture investors in winning business ventures in entrepreneurial competitions so as to obtain funding support Entrepreneurship. Entrepreneurship education implementation is the main teacher, they are the key to entrepreneurship education. Whether it is the teaching of theoretical and practical courses or the entrepreneurship lecture, teachers with entrepreneurial experience and business management are undoubtedly the best candidates for teaching entrepreneurship education. Colleges and universities should have their own entrepreneurial backbone team, external social success, industry experts as entrepreneurship education teachers. At the same time, we should regularly train teachers in full-time entrepreneurship education, organize teachers to go on business and entrepreneurship bases, conduct post-training and study assignments, and send outstanding teachers to enterprises, other colleges and universities or overseas study tours. Entrepreneurship education in colleges and universities cannot be run without qualified teachers, and colleges and universities can attract high-quality talents through many channels. At the same time, colleges and universities can attract successful entrepreneurs with practical experience to society and improve the teaching staff building for entrepreneurship education. Of course, you can also invite business success alumni or classmates to share business experience, to increase business confidence in college students.

\section{Conclusions}

Enrollment in higher education has made higher education more popular and the employment situation has become more and more severe. Entrepreneurship can promote the employment of university graduates. Strengthening entrepreneurship education of college students is an effective way to improve the status quo of college students' undertaking. Therefore, the government, society, universities, families and students should cooperate with each other to work together to establish a well-developed system of entrepreneurship education, which will help to improve the entrepreneurial rate and quality of employment of university graduates. 


\section{Acknowledgments}

Found Project No. 1320171015

\section{References}

[1] Xiao Min. Optimization research on entrepreneurial policies of undergraduates in Beijing from the perspective of small environment [J]. Value Engineering. 2017 (36)

[2] Jin Ying, Dai Junfeng. Studies on the plight and optimization of college students' Journal of Changchun Institute of Education. Journal of Changchun Institute of Education. 2017 (5)

[3] Qiao Zuqin. Research on the Construction of College Students' Innovation and Entrepreneurship System in Engineering College[J]. Journal of Jiangsu Economic and Technical Vocational Technical Institute. 2017 (06)

[4] Yang Heng. Guangzhou University Students Innovation and Entrepreneurship Research Report [J]. Modern Commerce. 2017 (33)

[5] Liu Jinghua. To enhance college students innovation and entrepreneurship policy targeted [J]. New Campus (early). 2017 (10) 